удк $347.91 / .95$

DOI https://doi.org/10.32837/apdp.v0i83.122

Г. Л. Крушельницька

\title{
ЗАКРИТТЯ ПРОВАДЖЕННЯ У ЦИВІЛЬНІЙ СПРАВІ У ЗВ’ЯЗКУ З ВІДСУТНІСТЮ ПРЕДМЕТА СПОРУ
}

Постановка проблеми. На відміну від попередньої редакції Цивільного процесуального кодексу України (далі - ЦПК України), що діяла до 15 грудня 2017 року, нова редакція серед підстав закриття провадження у справі передбачає відсутність предмета спору (п. 2 ч. 1 ст. 255 ЦПК України). Таке положення є новим для ЦПК України і було воно запозичене із господарського процесуального законодавства, тому його практичне застосування у цивільному процесі ще не набуло поширеності та однозначності. Зокрема проблема полягає у тому, що у ЦПК України відсутне визначення поняття предмета спору. Наявність цієї прогалини у цивільному процесуальному законодавстві породжує необхідність ï̈ дослідження і розроблення пропозицій щодо її усунення шляхом вироблення єдиного підходу до розуміння закриття провадження у справі у зв'язку із відсутністю предмета спору.

Аналіз останніх досліджень і публікацій. У науці цивільного процесуального права особливості закриття провадження у справі досліджували зокрема такі вчені як В.В. Комаров, В.А. Кройтор, В.І. Тертишніков, С.Я. Фурса, В.В. Масюк та інші. Проте питанню закриття провадження у справі у зв'язку із відсутністю предмета спору не приділено уваги взагалі, оскільки ця підстава саме у цивільному процесі $е$ новою. Власне і дослідження предмета спору проводилося лише у межах розробки поняття спору про право, якому присвячені наукові праці М.А. Гурвича, I.М. Зайцева, М.Д. Матієвського, М.М. Ненашева, Д.М. Чечота, Н.Ю. Сакари, І.В. Лимарь та інших. Однак, незважаючи на наявність наукових публікацій, відсутній уніфікований підхід до розуміння сутності предмета спору у цивільному судочинстві, що у свою чергу зумовлюе необхідність його теоретичного та практичного дослідження, у тому числі в розрізі питання про закриття провадження у справі через відсутність предмета спору.

Метою статті є розмежування понять предмета спору та предмета позову, а також визначення моменту, на який має бути відсутній предмет спору, для того, щоб утворити підставу для закриття провадження.

Виклад основного матеріалу дослідження. Закріпивши у п. 2 ч. 1 ст. 255 ЦПК України нову підставу для закриття провадження у справі у зв'язку із відсутністю предмета спору, законодавець не включив до ЦПК України правових норм, які б містили визначення поняття предмета спору. Така прогалина в цивільному процесуальному законодавстві, у свою чергу, призводить до змішування понять предмета спору та предмета позову, формуючи неоднозначність правозастосовної практики.

Таким чином, визначаючи особливості закриття провадження у цивільній справі на підставі відсутності предмета спору, насамперед необхідно з'ясувати поняття предмета спору та його співвідношення із поняттям предмета позову.

Так, C.I. Чорнооченко зазначає, що предмет позову складає його частина, яка характеризує матеріально-правову вимогу позивача до відповідача стосовно якої 
він просить постановити судове рішення. Таким чином, предмет позову повинен мати правовий характер і витікати з матеріально-правових відносин. При цьому він зауважує, що при характеристиці предмету позову необхідно відрізняти предмет позову в його безпосередньому розумінні від матеріального об’єкта [1, с. 170].

Так само і Є.О. Харитонов визначає предмет позову як частину позову, яка становить матеріально-правову вимогу позивача до відповідача, щодо якої суд повинен ухвалити рішення. Ця вимога повинна мати правовий характер, тобто бути врегульованою нормами матеріального права, а також підпадати під цивільну юрисдикцію [2].

С.В. Васильєв вказує, що предмет позову - це матеріально-правова вимога, заявлена позивачем в суд до відповідача щодо усунення допущеного відповідачем порушення суб'єктивного права позивача. Однак предмет позову не слід змішувати 3 певним речовим предметом спору, наприклад, конкретним об'єктом нерухомості, коштами тощо [3, с. 145].

П.Ф. Немеш під предметом позову розуміє те, стосовно чого позивач добивається захисту в суді: що він просить йому присудити, визнати чи змінити. Предметом позову є те, на що він спрямований [4, с. 96].

Із пункту 9 Постанови Пленуму Верховного Суду України від 12.06.2009 року № 5 «Про застосування норм цивільного процесуального законодавства, що регулюють провадження у справі до судового розгляду» випливає, що у правозастосовній практиці предметом позову є те, що конкретно вимагає позивач. Таким чином, у науці цивільного процесуального права та судовій практиці загальноприйнятним є підхід, згідно з яким предметом позову називають матеріально-правову вимогу позивача до відповідача, щодо якої суд має ухвалити рішення, при цьому предмет позову з речовий об'єктом позову не ототожнюється.

Що ж стосується поняття предмета спору, то М.Д. Матієвський до предмета спору включає як правову вимогу щодо вчинення протилежною стороною дій, які відповідають змісту суб'єктивного права, так і матеріальний об'єкт, що вимагається заінтересованою стороною [5, с. 14-19]. Натомість I.M. Зайцев зазначає, що предметом спору варто вважати правові вимоги сторін, тобто суб'єктивні права, щодо яких виник конфлікт [6, с. 40].

На думку Н.Ю. Сакари предметом спору є певні суб'єктивні права, свободи чи інтереси, яким у свою чергу має бути притаманна правова невизначеність, зумовлена як наявністю сумнівів щодо їх існування, так і обсягу, сфери дії або способу реалізації, при цьому спірними можуть виступати як питання права, так і питання факту, зокрема юридичного тлумачення тієї чи іншої норми права. Крім того, результат вирішення спору має бути визначальним для таких суб’єктивних прав, свобод чи інтересів, а не мати лише незначний зв'язок або віддалені наслідки, а суб'єктивне право, свобода чи інтерес, з приводу яких виникає спір, хоча б на «спірних» підставах має визнаватися в законодавстві [7, с. 66]. Таким чином, грунтуючись на підходах до визначення понять предмета спору та предмета позову, можна зробити висновок, що предмет спору є ширшим за предмет позову.

Як слушно зазначає Н.Ю. Сакара, за своєю природою юридичний спір завжди є допроцесуальним та позапроцесуальним явищем, що має матеріально-правовий 
характер. Під час його передачі на вирішення суду він трансформується в позов, який виступає безпосереднім об'єктом розгляду в межах відповідної цивільної справи [7, с. 67].

Отже, доцільно припустити, що предмет спору та предмет позову мають співпадати. Такої позиції притримуються у правозастосовній практиці. Так, у постанові Верховного Суду від 22 серпня 2018 року у цивільній справі за № 372/2230/17 зазначається, що «предметом спору» у цій справі є встановлення земельного сервітуту. Далі Верховний Суд, визначаючи передчасним висновок судів про тотожність «предмета спору», що стало наслідком закриття провадження у справі, зауважує, що позови вважаються тотожними, якщо в них одночасно збігаються сторони, підстави та «предмет спору». У розумінні цивільного процесуального закону «предмет позову» - це матеріально-правова вимога позивача до відповідача, стосовно якої він просить ухвалити судове рішення, отже не можна вважати, що між сторонами вже був вирішений «спір про той самий предмет» і позови повністю збігаються [8].

Вказаний підхід видається невірним з огляду на те, що обов'язковими елементами позову є предмет та підстава. Так, у ст. 175 ЦПК України встановлено, що однією з вимог щодо оформлення позовної заяви є викладення позивачем своїх вимог щодо предмета спору та їх обгрунтування. При цьому змістом позовних вимог $\epsilon$ спосіб (способи) захисту прав або інтересів, передбачений законом чи договором, або інший спосіб (способи) захисту прав та інтересів, який не суперечить закону і який позивач просить суд визначити у рішенні.

Згідно ст. 185 ЦПК України суддя, встановивши, що позовну заяву подано без додержання вимог, викладених у статтях 175 і 177 ЦПК України, протягом п’яти днів $з$ дня надходження до суду позовної заяви постановляє ухвалу про залишення позовної заяви без руху. Якщо позивач не усунув недоліки позовної заяви у строк, встановлений судом, заява вважається неподаною і повертається позивачеві. Таким чином, наявність чи відсутність предмета позову має встановлюватися на стадії відкриття провадження. Якщо судом буде встановлено, що предмет позову відсутній, і в подальшому позивач не усуне недоліки шляхом викладення матеріально-правових вимог до відповідача, очевидно, що провадження у справі відкрито не буде. Крім того, пунктом 8 ч. 1 ст. 257 ЦПК України передбачено, що суд постановляє ухвалу про залишення позову без розгляду, якщо провадження у справі відкрито за заявою, поданою без додержання вимог, викладених у статтях 175 i 177 ЦПК України і позивач не усунув цих недоліків у встановлений судом строк.

Автор доходить висновку, що предмет спору не ототожнюється з предметом позову і полягає не в матеріально-правовій вимогі позивача до відповідача, а являє собою суб’єктивні права, свободи чи інтереси, щодо яких виник конфлікт. Крім того, на основі комплексного аналізу статей ЦПК України, випливає, що у випадку виявлення відсутності предмета позову після відкриття провадження у справі, суд залишає позов без розгляду, а не закриває провадження у справі, як у випадку з відсутністю предмета спору.

Водночас на користь того, що предметом спору може бути також і матеріальний об’єкт, свідчить формулювання положень п. 1 ч. 1 ст. 152 ЦПК України, де зазначено, що заява про забезпечення позову подається «до суду за місцезнаходженням 
предмета спору - якщо суд, до підсудності якого відноситься справа, визначити неможливо». Оскільки місцезнаходження притаманне саме матеріальним об’єктам, очевидно, що йдеться про речовий предмет, щодо якого існує спір.

Наступним питанням, яке підлягає дослідженню у межах цієї наукової статті є визначення моменту, на який має бути відсутній предмет спору, для того, щоб слугувати підставою для закриття провадження.

Так, у пункті 4.4. Постанови Пленуму Вищого господарського суду України від 26.12.2011 року № 18 «Про деякі питання практики застосування Господарського процесуального кодексу України судами першої інстанції» визначено, що господарський суд припиняє провадження у справі у зв'язку з відсутністю предмета спору, зокрема, у випадку припинення існування предмета спору (наприклад, сплата суми боргу, знищення спірного майна, скасування оспорюваного акту державного чи іншого органу тощо), якщо між сторонами у зв'язку з цим не залишилося неврегульованих питань. Припинення провадження у справі на підставі зазначеної норми ГПК можливе в разі, коли предмет спору існував на момент виникнення останнього та припинив існування в процесі розгляду справи. Якщо ж він був відсутній і до порушення провадження у справі, то зазначена обставина тягне за собою відмову в позові, а не припинення провадження у справі.

Протилежної позиції притримується Верховний Суд у складі колегії суддів Першої судової палати Касаційного цивільного суду. У постанові від 10.04.2019 року по справі № 456/847/18 зазначено, що відсутність предмета спору унеможливлює вирішення справи по суті незалежно від обгрунтованості позову, а відповідно і здійснення ефективного захисту порушених, невизнаних або оспорюваних прав, свобод чи інтересів осіб. Поряд з цим за змістом п. 2 ч. 1 ст. 255 ЦПК України суд може закрити провадження у справі у зв'язку з відсутністю предмета спору, якщо встановить, що предмет спору був відсутній на час пред'явлення позову.

Логіко-граматичне тлумачення словосполучення «відсутність предмета спору» в контексті наведеної правової норми дає підстави для висновку про те, що предмет спору має бути відсутній, тобто не існувати на час пред’явлення позову. Якщо предмет спору мав місце, але припинив своє існування (зник) після відкриття провадження у справі внаслідок тих чи інших обставин, зокрема у зв'язку з добровільним врегулюванням спору сторонами, виконанням відповідачем заявлених до нього вимог, фізичним знищенням предмета спору тощо, то провадження у справі не може бути закрите з наведеної правової підстави, оскільки вона полягає саме у відсутності предмета спору, а не у припиненні його існування (зникненні).

Якщо предмет спору став відсутнім після відкриття провадження у справі, то залежно від обставин, що призвели до зникнення такого предмета, та стадії цивільного процесу, на якій він припинив своє існування, сторони мають цілий ряд передбачених законом процесуальних можливостей припинити подальший розгляд справи, зокрема шляхом залишення позову без розгляду, відмови від позову або від поданих апеляційних чи касаційних скарг, визнання позову відповідачем, укладення мирової угоди тощо [9].

Проте твердження, що суд може закрити провадження у справі у зв'язку з відсутністю предмета спору, «якщо встановить, що предмет спору був відсутній на час 
пред’явлення позову» $є$ виключно власним тлумаченням колегії суддів Верховного Суду, оскільки у ЦПК України не визначається момент, на який має бути відсутній предмет спору, аби суд міг закрити провадження у справі. Для того, щоб з'ясувати, що мав на увазі законодавець, видається необхідним проаналізувати в цілому положення ст. 255 ЦПК України, використовуючи запропоновану B.I. Тертишніковим класифікацію підстав закриття провадження у справі. Так, вчений поділяє такі підстави на три групи: перша група підстав зводиться до того, що в цих випадках справа в суді виникла незаконно, тобто при відсутності в позивача права на пред'явлення позову, а тому підлягає закриттю; друга група підстав полягає в тому, що справа виникла правомірно, але далі їі розглядати недоцільно; третя група підстав зводиться до того, що справа виникла правомірно, однак підлягає закриттю через неможливість подальшого їі розгляду [10, с. 228]. Таким чином, стаття 255 ЦПК України не усі підстави закриття провадження у справі відносить до випадків незаконного виникнення справи у суді, отже висновки колегії суддів Верховного Суду безпідставні. Так, відсутність предмета спору як підстава закриття провадження у справі може означати як те, що предмет спору був відсутній на час пред’явлення позову до суду, проте суду та/або позивачу про це не було відомо на момент відкриття провадження у справі, так і те, що предмет спору припинив своє існування після відкриття провадження на будь-якій стадії цивільного процесу.

3 огляду на вище викладене, показовою є постанова Верховного Суду від 3 травня 2018 року у справі № 404/251/17 (касаційне провадження № 61-13405св18). Згідно матеріалів справи позивач звернулась до суду з позовом про визначення додаткового строку для подання заяви про прийняття спадщини. Апеляційний суд провадження у справі закрив, мотивуючи тим, що позивач на час відкриття спадщини проживала разом зі спадкодавцем, тому відповідно до ч. 3 ст. 1268 ЦК України вважається такою, що прийняла спадщину. Оскільки позивач не пропустила строк для прийняття спадщини, суд вважав, що предмет спору відсутній, тому відповідно до п. 2 ч. 1 ст. 255 ЦПК України закрив провадження у справі. Проте Верховний Суд у складі колегії суддів Першої судової палати Касаційного цивільного суду не погодився з таким правовим висновком, постанову апеляційного суду скасував та передав справу на новий розгляд до суду апеляційної інстанції. Рішення було мотивовано, серед іншого, тим, що відсутність предмета спору унеможливлює вирішення справи по суті незалежно від обгрунтованості позову, а відповідно і здійснення ефективного захисту порушених, невизнаних або оспорюваних прав, свобод чи інтересів осіб. Оскільки право позивачки на спадщину оспорюється і навіть у разі доведення того, що вона не пропустила строку для прийняття спадщини, є невизначеність у правах і обов'язках сторін, у справі наявний іноземний елемент, це не дає підстав стверджувати про відсутність предмета спору у справі [11]. Такий висновок суду видається невірним. По-перше, провадження у справі підлягає закриттю не лише у зв'язку із неможливістю вирішення справи по суті, але й у зв'язку із недоцільністю подальшого розгляду справи. По-друге, предметом спору є суб'єктивні права, свободи, інтереси, щодо яких виник конфлікт або певний матеріальний об'єкт, з приводу якого виник спір, отже у разі відсутності суб'єктивного права, свободи, інтересу, конфлікту або матеріального об’єкту, суд 
закриває провадження у справі. Тобто в описаній вище справі в силу закону відсутній конфлікт щодо права позивача на прийняття спадщини, отже розглядати справу недоцільно, тому суд мав закрити провадження у справі. При цьому на момент відкриття провадження судом не досліджувалися докази, долучені до позовної заяви, отже зробити висновок про відсутність предмета спору стало можливим лише при розгляді справи по суті.

Останнім питанням, яке підлягає розгляду в межах цього дослідження, є процесуальна стадія, на якій суд закриває провадження у зв’язку з відсутністю предмета спору.

Відповідно до чинного процесуального законодавства України для відкриття позовного провадження достатнім $є$ викладене у позові твердження позивача про те, що його право, свобода або законний інтерес були порушені, невизнані або оспорені відповідачем. [12, с. 29] Тобто на стадії відкриття провадження суд не досліджує подані позивачем докази і не встановлює наявність чи відсутність предмету спору.

На основі аналізу статей 189 та 200 ЦПК України вбачається, що оскільки завданнями підготовчого провадження є остаточне визначення предмета спору, позовних вимог та характеру спірних правовідносин, встановивши відсутність предмета спору, в підготовчому засіданні суд постановляє ухвалу про закриття провадження у справі. Якщо предмет спору зникне у процесі розгляду справи по суті, то очевидно суд своєю ухвалою закриває провадження у справі на стадії розгляду справи по суті.

Якщо ж справа розглядається у порядку спрощеного позовного провадження, то провадження у справі може бути закрито у зв'язку з відсутністю предмету спору у будь-якому судовому засіданні, коли судом буде встановлено відсутність предмету спору.

Згідно ч. 1 ст. 377 ЦПК України судове рішення першої інстанції, яким закінчено розгляд справи, підлягає скасуванню в апеляційному порядку повністю або частково з закриттям провадження у справі з підстав, передбачених статтею 255 ЦПК України (зокрема у зв'язку зі встановленням відсутності предмету спору).

Відповідно до ч. 1 ст. 414 ЦПК України судове рішення, яким закінчено розгляд справи, підлягає скасуванню в касаційному порядку повністю або частково з закриттям провадження у справі з підстав, передбачених статтею 255 ЦПК України (зокрема у зв'язку зі встановленням відсутності предмету спору).

Таким чином, суд закриває провадження у справі у зв'язку із відсутністю предмета спору на будь-якій стадії після відкриття провадження, коли судом буде встановлено, що предмет спору відсутній взагалі або припинив своє існування після відкриття провадження у справі.

Крім того, ст. 44 ЦПК України передбачає неприпустимість зловживання процесуальними правами, серед яких залежно від конкретних обставин суд може визнати дії, що суперечать завданню цивільного судочинства, зокрема: подання позову за відсутності предмета спору. При цьому, згідно ст. 148 ЦПК України за зловживання процесуальними правами суд може постановити ухвалу про стягнення в дохід державного бюджету з відповідної особи штрафу. Отже поряд із постановленням ухвали про закриття провадження у справі на підставі відсутності пред- 
мета спору, суд може постановити ухвалу про застосування заходів процесуального примусу у вигляді штрафу до позивача, якщо він завідомо знав на момент пред'явлення позову, що предмет спору відсутній.

Висновки. Предмет спору не ототожнюється із предметом позову і полягає не в матеріально-правовій вимогі позивача до відповідача, а являє собою суб'єктивні права, свободи чи інтереси, щодо яких виник конфлікт. Предметом спору може бути також і матеріальний об’єкт, щодо прав на який виник конфлікт між сторонами. Більше того, на основі комплексного аналізу статей ЦПК України, випливає, що у випадку виявлення відсутності предмета позову після відкриття провадження у справі, суд залишає позов без розгляду, а не закриває провадження у справі, як у випадку із відсутністю предмета спору.

Відсутність предмета спору як підстава закриття провадження у справі може означати як те, що предмет спору був відсутній на час пред’явлення позову до суду, проте суду та/або позивачу про це не було відомо на момент відкриття провадження у справі, так і те, що предмет спору припинив своє існування після відкриття провадження на будь-якій стадії цивільного процесу.

Суд закриває провадження у справі у зв'язку із відсутністю предмета спору на будь-якій стадії після відкриття провадження, коли судом буде встановлено, що предмет спору відсутній взагалі або припинив своє існування у процесі розгляду цивільної справи.

\section{Jimepamypa}

1. Чорнооченко С.І. Цивільний процес : навч. посіб. для студ. вищ. навч. закл. Київ : «Центр учбової літератури», 2014. $416 \mathrm{c}$.

2. Харитонов Є.О. Цивільний процес України : навч. посіб. Київ : «Істина», 2012. 472 с.

3. Васильєв С.В. Цивільний процес України : навч. посіб. Київ : «Центр учбової літератури», 2013. $344 \mathrm{c}$.

4. Немеш П.Ф. Правове обгрунтування позову у цивільному процесі. Науковий вісник Ужгородського національного університету. Серія Право. 2018. Вип. 50. Том 1. С. 95-98.

5. Матиевский М.Д. Спор о праве в советском гражданском процессе: автореф. дис. ...канд. юрид. наук: 12.00 .03 . Москва, 1978.26 с.

6. Зайцев И.М. Сущность хозяйственных споров : монография. Саратов : Изд-во. Сарат. ун-та, $1974.157 \mathrm{c}$.

7. Сакара Н.Ю. Зміст та правова природа юридичного спору. Науковий вісник Ужгородського нащі онального університету. Серія Право. 2017. Вип. 46. Том 1. С. 63-68.

8. Постанова Верховного Суду від 22.08.2018 року у цивільній справі № $372 / 2230 / 17$ // Єдиний державний реєстр судових рішень. URL: http://reyestr.court.gov.ua/Review/76441538 (дата звернення 15.10.2019).

9. Постанова Першої судової палати Касаційного цивільного суду від 10.04.2019 року по справі № 456/847/18 // Єдиний державний реєстр судових рішень. URL: http://reyestr.court.gov.ua/ Review/81328756 (дата звернення 15.10.2019).

10. Тертишніков B.I. Цивільний процесуальний кодекс України: науково-практичний коментар. Видання шосте, доповнене й перероблене. Харків : Консул. 2002. 408 c.

11. Постанова Верховного Суду від 03.05.2018 року у справі № 404/251/17 // Єдиний державний реєстр судових рішень. URL: http://reyestr.court.gov.ua/Review/ 73868460 (дата звернення 15.10.2019).

12. Нижний А.В. Спір про право у цивільному процесуальному законодавстві та судовій практиці. Вісник Верховного Суду України. 2015. № 3 (175). С. 26-34. 


\section{Анотація}

Крушельницька Г. Л. Закриття провадження у цивільній справі у зв'язку з відсутністю предмета спору. - Стаття.

Наукова стаття присвячена дослідженню новели цивільного процесуального законодавства - закриттю провадження у справі на підставі відсутності предмета спору. Шляхом аналізу загальних норм цивільного процесуального права та застосування аналогії закону автор досліджує можливість вироблення науково обгрунтованих пропозицій для удосконалення цивільного процесуального законодавства.

Обгрунтовується необхідність розмежування понять предмета позову та предмета спору та недопустимість їх ототожнення. У статті проаналізовано різні доктринальні підходи до визначення поняття предмета позову та предмета спору. 3' ясовано, що предметом позову називають матеріально-правову вимогу позивача до відповідача, щодо якої суд має ухвалити рішення, при цьому предмет позову з речовим об’єктом позову не ототожнюється. У свою чергу предметом спору є суб'єктивні права, свободи чи інтереси, щодо яких виник конфлікт, а також матеріальний об'єкт спору.

Окрему увагу автором приділено дослідженню визначення моменту, на який має бути відсутній предмет спору, для того, щоб слугувати підставою для закриття провадження. Проаналізовано судову практику, виявлено суперечності у підходах господарських судів та судів загальної юрисдикції щодо припинення провадження у зв'язку із відсутністю предмета спору.

3'ясовано, що у господарському судочинстві провадження підлягає закриттю, якщо предмет спору існував на момент виникнення останнього та припинив існування в процесі розгляду справи. У цивільному судочинстві існує позиція, згідно якої у випадку, якщо предмет спору був відсутній на час пред'явлення позову, суд закриває провадження у справі.

3'ясовано, що обидва підходи є правильними, що відносить відсутність предмета спору одразу до двох груп підстав для закриття провадження: коли справа в суді виникла незаконно і коли справа виникла правомірно, але далі їі розглядати недоцільно. Досліджено, що суд закриває провадження у справі у зв'язку із відсутністю предмета спору на будь-якій стадії після відкриття провадження, коли судом буде встановлено, що предмет спору відсутній взагалі або припинив своє існування у процесі розгляду цивільної справи.

Ключові слова: юридичний спір, предмет спору, предмет позову, судовий розгляд, закінчення розгляду справи.

\section{Summary}

Krushelnytska $H$. L. The closing the proceedings in a civil case on the basis of the absence of the subject of dispute. - Article.

The scientific article is devoted to the dedicating of the novelty of the civil procedural legislation - the closing of proceedings in the case on the basis of the absence of the subject of dispute. By analyzing the general rules of civil procedural law and applying the analogy of law, the author explores the possibility of making scientifically sound proposals to improve civil procedural law.

The necessity to distinguish between the concepts of the subject of the claim and the subject of the dispute and the inadmissibility of their identification is substantiated. The article analyzes various doctrinal approaches to defining the concept of the subject of the claim and the subject of the dispute. It is established that the subject of the claim is called the substantive legal claim of the plaintiff to the defendant, for which the court has to decide, and the subject of the claim is not identified with the real object of the claim. In turn, the subject of the dispute is the subjective rights, freedoms or interests in which the conflict arose, as well as the substantive object of the dispute.

Particular attention is paid to the study of determining the point at which the subject of the dispute should be absent in order to serve as a basis for closing the proceedings. Case law has been analyzed and conflicts have been identified in the approaches of commercial courts and courts of general jurisdiction to stay proceedings due to lack of subject of the dispute.

It has been established that in commercial litigation proceedings are to be closed if the subject of the dispute existed at the time of its occurrence and ceased to exist in the course of the case. In civil proceedings, by contrast, there is a position that, if the subject of the dispute was absent at the time of the claim, the court closes the proceedings. It has been found that both approaches are correct, which attributes the absence of the subject of the dispute to two groups of grounds for closing the proceedings: when the case was brought illegally and when the case was lawful, but it should not be considered further. It has been investigated that the court closes the proceedings in connection with the lack of the subject of the dispute at any stage after the opening of the proceedings, when the court finds that the subject of the dispute is absent or ceased to exist during consideration of the civil case.

Key words: legal dispute, subject of dispute, the subject of the claim, trial, the end of the case. 